\title{
The prospects and problems of e-commerce in Azerbaijan in the context of globalization
}

\author{
Leyla Hajiyeva ${ }^{1, *}$ \\ ${ }^{1}$ Azerbaijan State University of Economics, Department of Economics, Istiglaliyyat, 6, Baku AZ1001, \\ Azerbaijan
}

\begin{abstract}
Research background: With globalization on the Internet, the economy is gaining a wide range of new opportunities. The economic activity carried out using the latest IT - technologies is effective and profitable. E-commerce is one of the main components of the "new economy", which is gaining increasing practical importance. The effectiveness of electronic commerce is determined by the fact that with this form of trading transaction costs are reduced, i.e. the costs associated with the search and processing of information, negotiating and signing contracts, as a result of which the process of buying and selling and concluding transactions is simplified, opportunities for attracting investments are expanded, and geographical accessibility is improved. Online commerce in Azerbaijan is at the development stage and has broad prospects for further growth.

Purpose of the article: The main goal of the article is to analyze the possibilities of developing online commerce in Azerbaijan and evaluate the factors influencing its development in the context of globalization.

Methods: The author carries out a comparative analysis of the development of online commerce in a number of countries, uses a systematic approach to analyze the main problems that limit the development of e-commerce in Azerbaijan.

Findings \& Value added: The article analyzes the main problems limiting the development of online commerce in the country and contain a number of recommendations for the further development of e-commerce in Azerbaijan.
\end{abstract}

Keywords: -commerce, internet users, online trading, e-stores

JEL Classification: $O 14 ; R 11 ; F 61$

\section{Introduction}

One of the main tendencies in the development of the modern economy is globalization, which affects the transformation of all spheres of public life and strengthens the interdependence of individual countries and regions.

*Corresponding author: Leyla Hajiyeva@unec.edu.az 
As a result of globalization, a global economy, a single geopolitical and socio-cultural space is being formed, and existing national borders in politics, economics, science, engineering and technology, information, law, education, and culture are disappearing. Today, globalization goes through a new phase of its development in terms of quality, which is characterized by the development of information and communication technologies (ICT), the widespread use of the Internet and mobile communications.

Modern advances in the development of global information and communication technologies have led to the rapid development of economic activity called "e-commerce". The development and increase in the volume of e-commerce are accompanied by some positive effects for the global economy. These include: reducing transaction costs, simplifying trade procedures, expanding opportunities for investment flows, expanding the geographical area and accessibility of business, and increasing competition. Currently, the whole world is encountering the challenges of the dangerous COVID-19 virus, which has been declared a pandemic by the WHO. Many traditional industries have completely gone belly up, especially the service sector. In this context, the development of e-services, including e-commerce, is of particular importance.

Let's take a look at the basic concepts of e-commerce. Kim and Moon were authors of the initial definitions of e-commerce. According to their definition, electronic commerce is the use of computer networks and other electronic tools to sell and deliver goods and services. [1]. K. C. Laudon and C.G. Traver note that "E-commerce involves the use of the Internet, the World Wide Web (Web), and mobile apps and browsers running on mobile devices to transact business" [2].

Efraim Turban, Jon Outland, David King, Jae Kyu Lee, Ting-Peng Liang and Deborrah C. Turbandescribe e-commerce as the purchase and sale of products and services using the Internet and other networks [3]. In his study, Sarbapriya Ray points out the direct link of ecommerce with globalization and digitalizationand describes e-commerce "As a symbol of globalization" [4].

Many authors claim that e-commerce should not be limited to the purchase and sale of goods and services via the Internet. The main concept is the implementation of profitable exchanges using information communications. E. Turban, Jae K. Lee, and David Kingnote that e-commerce is not only the purchase and sale of goods and services, but also a broader concept related to the transfer of goods, services and information through information and communication networks [5].Z. Qin's book reflects the definitions of e-commerce by transnational companies Intel, IBM, and HP[6].E-commerce shall be social, economic activities between social principal parts by taking advantages of computers and network. The definition given by the WTO also emphasizes that e-commerce is the production, delivery and sale of goods and services through communication networks [7]. Salo E. define ecommerce from various aspects such as Communication, Business, Service and Online perspective [1]. V. Starostin and V. Chernova note the role of online shopping, social media and marketing in e-commerce business [8]. Based on these definitions, it can be concluded that e-commerce is the implementation of profitable exchanges through telecommunications networks.

A number of authors have examined the main factors affecting online shopping. So, some studies note the role of such factors as price and availability[9],others highlightthe role of price and product uniqueness in online shopping [10].According to K. Bredzel-Skowera and T.T ure the main factors affect on online shopping are good price, low delivery costs, and bargains[11].Charles Ayo notes the special role of internet access and payment cards availability in the development of e-commerce [12].R. J. Nathan et al and A. J. Chin et al also emphasize the role of social factors and trust as fundamental factors driving online commerce[13, 14]. S. Bae and T. Lee focus on gender differences in online shoppers [15]. Gender differences in consumer perception of online shopping are considered in studies $[16$, 
17]. Let's consider the development of online commerce in Azerbaijan and analyze the main factors affecting online shopping.

\subsection{E-commercein Azerbaijan}

At present, along with the traditional oil sector in Azerbaijan, the development of the non-oil sector, including the development of information communications and the establishment of an information society, is a priority. The development concept "Azerbaijan 2020: the vision for the future" adopted in 2011 sets several tasks, of which we can mention the following: Ensuring the transition to the information society; creation of a knowledge economy; diversification of ICT application in state and local government structures, development of e-services; establishment of the National Center for E-Security and acceleration of its activity; fully addressing the needs of the society members for ICT products and services; strengthening export-oriented and competitive ICT potential. A "Digital Trade Hub of Azerbaijani" has been established in the country, which allows for the preparation and signing of documents, including contracts in electronic form, as well as the implementation of cross-border electronic services in real-time between persons registered as taxpayers and their foreign business partners. On May 10, 2005, the Law of the Republic of Azerbaijan "On Electronic Commerce" was adopted. All rights and obligations, including the responsibilities of the parties related to e-commerce, are regulated by this law [18]. However, due to the lack of an online payment system, the first steps in this field were taken in Azerbaijan in 2008. The expansion of e-commerce and the development of e-payment systems is one of Azerbaijan's commitments. The development of e-commerce is also one of the priorities of the State Program on "E-Government". On December 2, 2008, "SilverKey Azerbaijan" company established the first online payment system - "GoldenPay" in the country, which was awarded the exclusive licenses of Visa and MasterCard and presented it to companies and government agencies. According to researches, citizens are more likely to order cars, mobile phones, clothing, cosmetics, and cheap jewelry online. Prices for online sales are also much lower than regular prices at shops.

Online shopping has many advantages, including time and money savings, a wide range of options, convenience, and a simplified purchase procedure. From this point of view, the development of e-commerce has been observed in Azerbaijan since 2008. According to the [19], in January-March 2020, products of 10.1 million manats were sold in the electronic retail network in the country. This is 1.7 times more with comparable prices than in JanuaryMarch 2016.However, according to experts, e-commerce in Azerbaijan accounts for only 4\% of traditional trade transactions. For comparison, 80 percent of trade in the United States and 60 percent in Europe is done electronically. Therefore, given the low share of taxes in the state budget, the Azerbaijani government should be directly interested in developing this field.

The development of e-commerce is directly related to the development of internet and information communications [20]. In 2018, Azerbaijan reached a 21\% pace of development in the ICT sector, and due to the use of the Internet has become one of the leaders among the CIS countries. According to the project, implemented in the framework of the "optics for home" model by the State Oil Fund together with the Ministry of Communications and Information Technologies, the majority of the entire population, including remote villages of Azerbaijan has been provided with broadband internet with the speed of $10-100 \mathrm{Mb} / \mathrm{s}$. Individuals and firms that have access to broadband Internet can act as buyers or sellers in their commercial activities, and in turn can transfer operations from the physical environment to the electronic one, which creates a favorable environment for e-commerce operations and the development of e-business [21].Let's look at the main infrastructure indicators of ICT in Azerbaijan (Figure 1). 


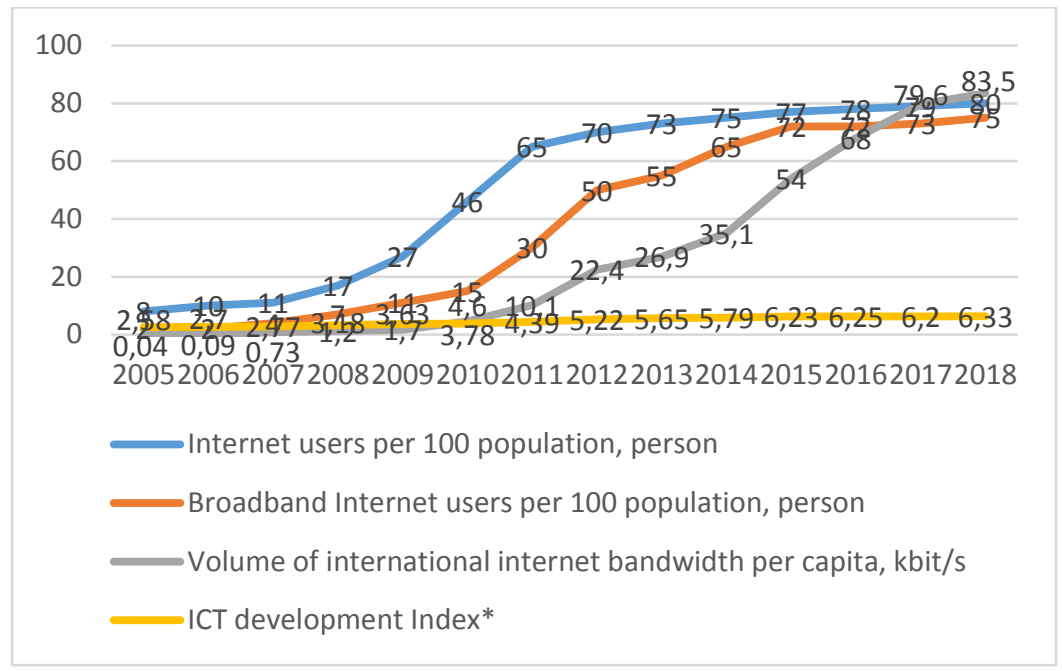

Fig. 1: İndicators on İCT infrastructure in Azerbaijan [19]

As can be seen from the graph, during the study period, the ICT infrastructure in the country has developed significantly, including the number of Internet users per 100 people increased by 10 times and reached from 8 to 80 . The number of broadband Internet users increased by 37.5 times (from 2 to 75 ), and the volume of international Internet channels per capita increased from $0.04 \mathrm{kbit} / \mathrm{s}$ to $83.5 \mathrm{kbit} / \mathrm{s}$ (by 2087 times), which had a positive impact on the ICT development index and reached from 2.58 to 6.33 (2.45 times).

One of the interesting issues for research is the purpose of using the Internet. This information is reflected in Figure 2.

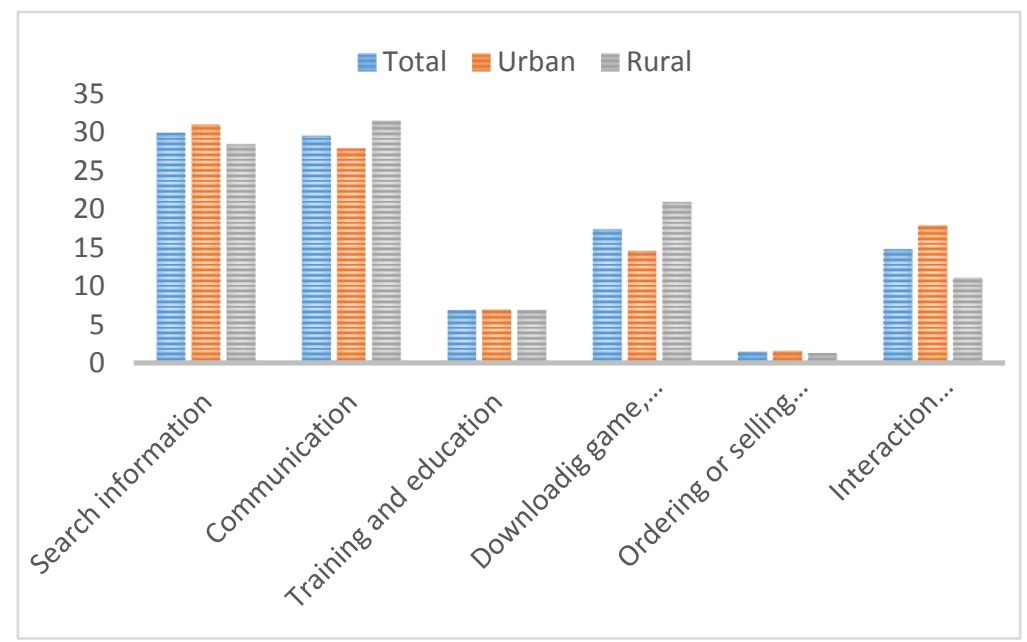

Fig. 2. Purposes of use of Internet network, as \% to total, 2018 [19]

As can be seen from the diagram, in 2018, the majority of Internet users are online information seekers and communicators. Only 1.5 percent of users ordered goods and services via the Internet, which is the lowest figure.

Another issue of interest for the study is the age of Internet users of which data is reflected in Figure 3. 


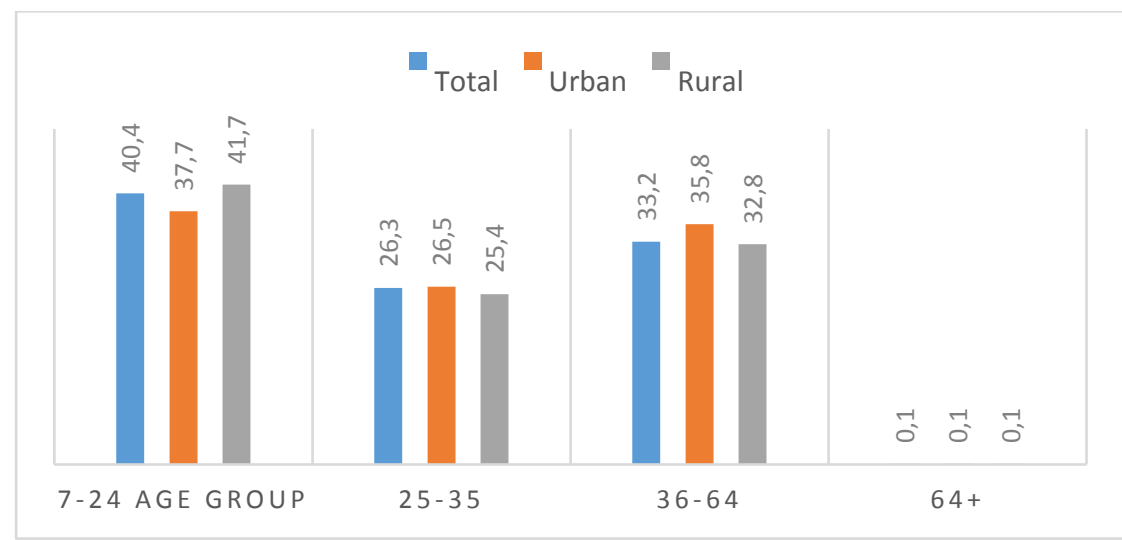

Fig. 3. Distribution of internet users by age groups, 2018 [19]

According to statistics, the largest group of Internet users in Azerbaijan is 7-24 years old, most of whom are teenagers and students who do not belong to the working population, and another noteworthy fact is that the population over 64 years old are not internet users (only $0.1 \%$ ). Both graphs (Figs. 2 and 3 ) show that there is not much difference between the urban and rural populations in terms of Internet use.

When analyzing the current state of e-commerce in Azerbaijan, it is possible to assess the situation by the purchase and sale transactions of consumers through foreign or local ecommerce portals. The assessment reveals that the volume of purchases from foreign ecommerce resources is many times higher. The main reason for this is the wide range of goods and low prices. Although there are local e-commerce sites, their turnover is much lower than that of international e-commerce portals, and most of them fall into the share of service providing sites more than shopping. The service companies which provide insurance, food delivery, courier services, travel, etc. are more popular.

According to 2018, the most popular search engines in the country are: Google $(92,3 \%)$, Yahoo! (2,51\%), Bing (2,28\%), Baidu (0,85\%), Yandex.ru (0,61\%), DuckDuckGo $(0,33 \%)$. The most commonly used browsers are Chrome $(68,69 \%)$, Opera $(8,82 \%)$, Safari $(7,39 \%)$, Samsung Internet (7,26\%), Android (2,94\%) and Yandex browser (1,3\%).

One of the factors influencing the development of e-commerce in the country is the existence of a secure payment system and means of payment. In 2008, "hesab.az", the first national online payment system offered by SilverKey Azerbaijan and working with the Golden Pay system, was launched. The turnover of new services on Hesab.az, the largest payment portal in Azerbaijan, is growing 4-5 times a year. Besides, the website "million.az" was created by the company "KomtecLtd" (trademark MilliON) and offered its e-payment services. Currently, through both portals, it is possible to make payments for services of utilities, internet, mobile and landline phones, advertising, leasing, payment cards, e-wallets, smart shopping, cable TV, banking, insurance, e-shop, etc.

\section{Methods}

\subsection{Comparative analysis of e-commerce development in selected countries}

The development of e-commerce is influenced by some factors, including the economic situation in the country and the development of information communications. Let's look at some statistics and compare the data of selected countries. It should be noted that some of these countries were bordering on Azerbaijan (Turkey, Russia, Iran, Georgia, Armenia), 
while other countries, as post-Soviet countries, have long developed in the same political and economic environment as Azerbaijan (Ukraine, Belarus, Kazakhstan, Uzbekistan).

According to statistics, the number of Internet users in the world increased from 1.1 billion (2005) to 4 billion, the global penetration rate increased from $16.8 \%$ to $53.6 \%$ over the period from 2005 to 2019 [22]. The number of Internet users in Azerbaijan in 2019 was $7,991,630$, which was $78.8 \%$ of the population. For comparison, this figure was $66.6 \%$ in Georgia, 78.9\% in Kazakhstan, 93.6\% in Russia, 81.9\% in Turkey, 93.5\% in Ukraine, 51.3\% in Uzbekistan, $79.6 \%$ in Belarus, $80.5 \%$ in Iran and $71.8 \%$ in Armenia (Table 1).

Table 1.Statistics of selected countries [23]

\begin{tabular}{|l|c|c|c|c|}
\hline Country & $\begin{array}{c}\text { Population } \\
\mathbf{( 2 0 2 0 )}\end{array}$ & $\begin{array}{c}\text { GDP (per } \\
\text { capita, \$) }\end{array}$ & $\begin{array}{c}\text { Number of Internet users } \\
\text { (december, 2019) }\end{array}$ & $\begin{array}{c}\text { Penetration, } \\
\text { \%, per IWS }\end{array}$ \\
\hline Azerbaijan & 10139177 & 4721 & 7991630 & 78.8 \\
\hline Belarus & 9449323 & 6289 & 7521628 & 79.6 \\
\hline Russia & 145934462 & 4302 & 1693942 & 93.6 \\
\hline İran & 83992949 & 5627 & 67602731 & 80.5 \\
\hline Georgia & 3989167 & 4717 & 2658311 & 66.6 \\
\hline Ukraine & 43733762 & 3095 & 40912381 & 93.5 \\
\hline Turkey & 84339067 & 9370 & 69107183 & 81.9 \\
\hline Kazakhstan & 18776707 & 9812 & 14669853 & 78.9 \\
\hline Armenia & 2963243 & 4212 & 2126716 & 71.8 \\
\hline Uzbekistan & 33469203 & 1532 & 17161534 & 51.3 \\
\hline
\end{tabular}

Analysis of the statistics of the selected countries shows that the highest penetration rates belong to Russia (93.6\%) and Ukraine (93.5\%), while the lowest rates are in Georgia (66.6\%) and Uzbekistan (51.3\%). Azerbaijan ranked 7th among 10 selected countries (penetration $78.8 \%$ ). Among the countries selected in terms of GDP per capita, Kazakhstan and Turkey have the highest rates, while Uzbekistan and Ukraine have the lowest. Azerbaijan ranks 5th among 10 countries.

The United Nations Conference on Trade and Development (UNCTAD) calculates the ecommerce development index to determine the level of development of e-commerce in different countries. This index for 2019 is calculated based on 152 countries. The index is calculated on four key indicators that affect online shopping, including Share of individuals using the Internet, Share of individuals with an account, Secure Internet servers, and UPU (Universal Postal Union) postal reliability. Let's look at Azerbaijan's B2-C E-commerce index and make comparisons between selected countries. (Table 2).

The highest B2C E-commerce index among the selected countries was Belarus in 2019 by holding 37 th place, Azerbaijan was 8 th among 10 countries (rank 62). Compared to the Index rank of 2018, our country has advanced by 6 points, which indicates a positive trend in the development of e-commerce. According to the indicators of our country, the share of individuals using the Internet is quite high (80\%), according to this indicator, Azerbaijan is in 2 nd place among 10 countries (1st place owned by Russia $81 \%$ ), and the weakest indicator is in Uzbekistan (52\%). Another high indicator is UPU Postal reliability, according to which we share 4-5 places with Belarus, Georgia (99) in the first place and Uzbekistan (41) in the last place. According to the Share of individuals with account indicators, the lowest results fall into Azerbaijan (29\%) and the highest into Iran (94\%). Our other weak indicator is Secure Internet servers, we are in 8th place with 53 points (the highest indicator is 76 in Ukraine, the lowest is 51 in Uzbekistan). In 2018, the Index value was 61.8, we were in 8th place among 10 countries, the first was Belarus (79.3), the last was Uzbekistan (45.4). Thus, the analysis of the B2C E-commerce index of the selected countries shows that despite the positive development trends in our country in recent years, several problems still exist. To achieve better results, it was necessary to increase the security of Internet servers and increase the 
number of individuals with accounts. In the next section, we will analyze the problems of our country in the field of e-commerce in more detail.

Table 2.UNCTAD B2C E-commerce index, 2019 [24]

\begin{tabular}{|l|l|c|c|c|c|c|c|c|}
\hline $\begin{array}{c}2019 \\
\text { rank }\end{array}$ & Economy & $\begin{array}{c}\text { Share of } \\
\text { individuals } \\
\text { using the } \\
\text { internet } \\
(2018 \text { or } \\
\text { latest })\end{array}$ & $\begin{array}{c}\text { Share of } \\
\text { individuals } \\
\text { with an } \\
\text { account } \\
(15+? \\
2017 \text { or } \\
\text { latest })\end{array}$ & $\begin{array}{c}\text { Secure } \\
\text { Internet } \\
\text { servers } \\
(2018)\end{array}$ & $\begin{array}{c}\text { UPU } \\
\text { postal } \\
\text { reliability } \\
(2018 \text { or } \\
\text { latest })\end{array}$ & $\begin{array}{c}\text { Index } \\
\text { value } \\
(2018 \\
\text { data })\end{array}$ & $\begin{array}{c}\text { Index } \\
\text { value } \\
\text { change } \\
(2017- \\
2018 \\
\text { data })\end{array}$ & $\begin{array}{c}2018 \\
\text { Index } \\
\text { rank }\end{array}$ \\
\hline 37 & Belarus & 79 & 81 & 71 & 86 & 79.3 & -0.1 & 37 \\
\hline 40 & Russia & 81 & 76 & 75 & 80 & 77.9 & 1.5 & 42 \\
\hline 42 & Iran & 70 & 94 & 56 & 88 & 76.9 & 1.1 & 49 \\
\hline 50 & Georgia & 64 & 61 & 68 & 99 & 73.1 & -1.5 & 46 \\
\hline 52 & Ukraine & 59 & 63 & 76 & 92 & 72.5 & -1.1 & 51 \\
\hline 53 & Turkey & 71 & 69 & 73 & 74 & 71.8 & -1.4 & 47 \\
\hline 57 & Kazakhstan & 79 & 59 & 64 & 72 & 68.5 & -2.3 & 53 \\
\hline 62 & Azerbaijan & 80 & 29 & 53 & 86 & 61.8 & -1.5 & 68 \\
\hline 78 & Armenia & 65 & 48 & 53 & 49 & 53.7 & -10.4 & 66 \\
\hline 93 & Uzbekistan & 52 & 37 & 51 & 41 & 45.4 & -8.4 & 86 \\
\hline
\end{tabular}

\section{Results and Discussion}

\subsection{Problems and prospects of developing e-commerce in Azerbaijan}

Research on the development of online commerce in our country shows that there are many problems in this field. One of the main problems is the incomplete formation of the legal framework of e-commerce. Although the Law on e-commerce has been adopted, there is a need to adopt additional legislative acts regulating the development of this field. Some decisions may even seriously hinder the development of e-commerce, for example, the decision of the Cabinet of Ministers of August 22, 2020, reduced the limit on the value of duty-free goods imported by individuals from $\$ 1,000$ to $\$ 300$ per month. Purchases exceeding this amount will be subject to value-added tax. Of course, such decisions create restrictions for people who face economic problems in a pandemic and prefer online commerce. Another problem is the lack of regulation of activities of Internet providers - the high cost of Internet packages and the low level of service. It should be noted that in previous years there was a sharp difference in Internet use between urban and rural populations, but in recent years, and especially in 2018 , this difference has reached a minimum. It can be assessed as a positive result. However, the low quality and speed of the Internet, high tariffs compared to neighboring countries create many problems for users, which harms the development of e-commerce.

Although the number of Internet users is large, most people use it for entertainment and information purposes. The users of online shopping make up the smallest group. The main reasons for this are that the majority of Internet users are members of the younger generation and do not actively participate in purchase and sale; it is also worth noting that people do not have the habit of e-commerce.

Another problem with the security of electronic payment systems is that some consumers are reluctant to post their personal information on the Internet. One of the main indicators of the delay in the development of e-commerce in Azerbaijan is the presence of plastic cards in a small part of the population. Some plastic cards - about $80 \%$ - are issued to citizens for the 
payment of salaries and pensions. On the other hand, people often use plastic cards to withdraw cash from ATMs. This is because there is less understanding of the rules of use of plastic cards and almost lack of awareness-raising activities. However, in modern times, plastic cards are understood as a tool to limit the circulation of cash and integrate into the sphere of e-commerce. Approaching from this perspective, the development of e-commerce and its share in the overall trade turnover will depend on the awareness-raising activities in this area. Despite these problems, there are positive trends in the development of e-commerce in Azerbaijan, such as an increase in the country's B2C e-commerce index, public awareness of the benefits of e-commerce, the creation of e-commerce Public Union, which combines ecommerce platforms in the country. The development of e-commerce will increase the transparency of the tax system, as all online transactions are recorded and subjected to the tax. For the development of e-commerce in the country, first of all, it is necessary to more actively involve people in this field by applying certain concessions and taking concrete steps.

Summarizing the research, it can be concluded that the main factors affecting the development of e-commerce in Azerbaijan can be divided into two groups: restrictive and stimulating factors. It is necessary to have new incentives for the development of e-commerce and to create a more favorable environment for online commerce in the country (Table 3 ).

Table 3. Factors affecting the development of e-commerce

\begin{tabular}{|l|l|l|}
\hline \multicolumn{1}{|c|}{ Factors } & \multicolumn{1}{|c|}{ Limiting } & \multicolumn{1}{|c|}{ Stimulating } \\
\hline Legal & $\begin{array}{l}\text {-The legal framework for regulating online trading } \\
\text { has not been formed } \\
\text {-A new decree of the Cabinet of Ministers to } \\
\text { reduce the amount of duty-free import of goods } \\
\text { through online orders from \$ 1,000 to \$ } 300 \text { (for } \\
\text { individuals) }\end{array}$ & $\begin{array}{l}\text { Law of Azerbaijan Republic } \\
\text { on e-commerce }\end{array}$ \\
\hline Economic & $\begin{array}{l}\text { - instability of the economic situation } \\
\text { - Existence of shadow economy } \\
\text { - high monopoly of industry, communications and } \\
\text { transport } \\
\text { - Lack of a single pricing mechanism } \\
\text { - Lack of a business-friendly tax system } \\
\text {-complete use of available resources } \\
\text {-unfavorable investment climate }\end{array}$ & $\begin{array}{l}\text {-increase in income } \\
\text {-increase in GDP per capita } \\
\text { - the need to increase the } \\
\text { efficiency of supply and } \\
\text { marketing activities in } \\
\text { companies } \\
\text {-development of internet } \\
\text { banking }\end{array}$ \\
\hline $\begin{array}{l}\text { Infrastruc- } \\
\text { ture }\end{array}$ & $\begin{array}{l}\text { - Low rate of development of information } \\
\text { technologies compared to developed countries } \\
\text {-weak development of telecommunications } \\
\text {-Low speed and quality of the Internet }\end{array}$ & $\begin{array}{l}\text { - High volume of } \\
\text { international Internet } \\
\text { channels per capita }\end{array}$ \\
\hline Social & $\begin{array}{l}\text { Low e-shopping habits of the population } \\
\text { Distrust of electronic payment systems } \\
\text { Less use of plastic cards in sales transactions }\end{array}$ & $\begin{array}{l}\text {-High number of Internet } \\
\text { users } \\
\text {-Establishment of E- } \\
\text { commerce Public Union }\end{array}$ \\
\hline
\end{tabular}

\section{Conclusion}

As e-commerce is a new field for our country, there are many problems in its development. Our research shows that the development of e-commerce in Azerbaijan is low among the selected countries and the main reasons for which are the incomplete legal framework governing e-commerce in the country, monopolies in many areas (including in retail), high customs duties, lack of a unified mechanism for pricing system, low use of plastic cards for shopping, problems with the security of online payments, expensive and low-quality services 
of Internet providers, the small number of national online shopping portals.

However, the positive tendencies observed, including the rise of our country from 68th to 62nd place according to the UNCTAD B2-C E-commerce index, the high number of Internet users in the country, increasing incomes, the popularity of online commerce among young people and in particular, the fact that e-commerce has become a priority over traditional commerce during the pandemic period shows that there are broad prospects for the development of online commerce in Azerbaijan.

Necessary steps for the development of e-commerce in the country:

- Creation of a legal framework governing the development of e-commerce as soon as possible.

- Clarification of the pricing mechanism.

- Carrying out tax policy supporting online trade.

- Regulation of the activity of Internet providers, the establishment of standards regulating the speed and quality of the Internet and close to world standards.

- Development of national online stores.

- Promotion of e-commerce among the population (especially the elderly).

\section{References}

1. Salo, E. (2014). Adaptation of Maspart.com to Russian e-commerce. Retrieved from: https://www.theseus.fi/bitstream/handle/10024/71084/Esko\%20Salo.pdf?sequence=1

2. Laudon, K., Traver, C. (2017). E-commerce 2017: Business, Technology, Society. $13^{\text {th }}$ edition. Pearson Education, Inc.

3. Turban E., Outland J., King D., Lee J.K., Liang T., Turban D.C., (2018). Electronic Commerce 2018, A Managerial and Social Networks Perspective. $9^{\text {th }}$ edition. Springer.

4. Ray, S. (2011). Emerging Trend of E-Commerce in India: Some Crucial Issues, Prospects and Challenges. Computer Engineering and Intelligent Systems, 2(5), 17-35.

5. Turban, E., Lee, J., King, D. (2006). Electronic Commerce: A Managerial Perspective, Prentice Hall.

6. Zheng Q. (2009). Introduction to E-commerce, Tsinghua University Press: Springer.

7. Mohamed E., Wang P., Elhadi O. (2014). E-commerce in Sudan: The Reality and Prospects. In Q. Hu (Ed.), Proceedings of the 2014 International Conference on Management Science and Management Innovation. (pp. 82-88), Changsha: China.

8. Starostin, V., Chernova, V. (2016). E-commerce development in Russia: trends and prospects. Journal of Internet Banking and Commerce, 21(5).

9. Bucko, J., Kakalejcik, L., Ferencova, M. (2018). Online shopping: Factors that affect consumer purchasing behavior. Cogent Business \& Management, 5(1), Art. No. 1535751.

10. Huang, S., Chang, Y. (2019). Cross-border e-commerce: consumer's intention to shop on foreign websites. Internet Research, 29(6), 1256-1279.

11. Bredzel-Skoweraa, K., Ture, T. (2015). The Prospects of E-commerce in Poland. Procedia Computer Science, 65, 1114-1123.

12. Ayo Ch. (2006). The Prospects of E-Commerce Implementation in Nigeria. Journal of Internet Banking and Commerce, 11(3).

13. Nathan, R., Victor, V., Lay, G., Kot, S. (2019). Electronic commerce for home-based businesses in emerging and developed economy. Eurasian Business Review, 9(4), 463483. 
14. Chin A., Wafa S., Ooi A. (2009). The Effect of Internet Trust and Social Influence towards Willingness to Purchase Online in Labuan, Malaysia. International Business Research, 2(2), 72-81.

15. Bae, S., Lee, T. (2011). Gender differences in consumers' perception of online consumer reviews. Electronic Commerce Research, 11(2), 201-214.

16. McLaughlin C., McCauley L., Prentice G., Verner E., Loane S. (2020). Gender differences using online auctions within a generation Y sample: An application of the theory of Planned Behaviour. Journal of Retailing and Consumer Services. 56, Art. No. 102181.

17. Mann M., Liu-Thompkins Y. (2019). Shopping online? The role of imagination and gender. European Journal of Marketing, 53(12), 2604-2628.

18. Suleymanov, E., Ibrahimova, Kh. (2018). Perspectives of E-Commerce Development in Azerbaijan. SSRN Electronic Journal, Retrieved from: http://dx.doi.org/10.2139/ssrn.3299851

19. Information Society. Statistical publication. (2020). State Statistical Committee. Retrieved from: https://www.stat.gov.az/source/information_society

20. Tomar V., Khattri V. (2019). Internet usage and its impact on perception towards online shopping. Pacific Business Review International, 12(6), 47-60.

21. Azerbaijan: Country Digital Development Overview (2019). Asian Development Bank. Retrieved from: https:/www.adb.org/sites/default/files/institutionaldocument/484586/aze-digital-development-overview.pdf

22. Measuring digital development. Facts and figures. (2019). International Telecommunication Union. Retrieved from: https://www.itu.int/en/ITU$\mathrm{D} /$ Statistics/Pages/facts/default.aspx

23. Internet World Stats. Retrieved from: https://www.internetworldstats.com/

24. UNCTAD B2C E-Commerce Index 2019. United Nations Conference on Trade and Development. Retrieved from: https://unctad.org/en/PublicationsLibrary/tn_unctad_ict4d14_en.pdf 